\title{
In vitro toxicity and control of Meloidogyne incognita in soybean by rosemary extract
}

\section{Toxicidade in vitro e controle de Meloidogyne incognita em soja por extrato aquoso de alecrim}

\author{
Mônica Anghinoni Müller ${ }^{*}$; Thaísa Muriel Mioranza²; \\ José Renato Stangarlin ${ }^{3}$; Odair José Kuhn ${ }^{3}$; Andre Gustavo Battistus ${ }^{4}$; \\ Ademar Novais Istchuk ${ }^{5}$; Felipe Fuchs ${ }^{5}$
}

\begin{abstract}
The control of nematodes in plants can be challenging, and there is a need for alternative, environmentally conscious methods for their management. The purpose of this study was to evaluate the effect of rosemary extract (Rosmarinus officinalis) on the in vitro toxicity and control of Meloidogyne incognita in CD 206 and CD 215 soybean cultivars. Using an in vitro assay, $500 \mathrm{M}$. incognita eggs per plate were observed for 15 days after incubation with rosemary extract at concentrations of $1 \%, 5 \%$, and $10 \%$. Soybean plants were studied under greenhouse conditions, and starting at V3 stage, were sprayed weekly with the same concentration of rosemary extract for 64 days. Three days after the first treatment, each soybean plant was inoculated with 1800 eggs and 400 second-stage juveniles (J2). At the end of this essay, number of eggs and J2 in the roots and soil, number of galls, and the reproduction factor (RF) were evaluated. Our results showed that in the in vitro assay, rosemary extract reduced the number of M. incognita eggs that hatched. Under greenhouse conditions, the CD 206 cultivar showed a 46.5\% reduction in the number of galls, as well as fewer eggs in the soil and a lower RF. Similarly, in the CD 215 cultivar, the number of eggs was reduced and the RF was lower. These results indicate the potential for rosemary extract to control M. incognita in soybean crops.
\end{abstract}

Key words: Alternative control, resistance induction, root-knot nematode, rosemary extract

\section{Resumo}

Devido à dificuldade de manejo de nematoides e a necessidade de desenvolver métodos alternativos de controle, objetivou-se avaliar a toxicidade in vitro do extrato aquoso de alecrim (Rosmarinus officinalis), assim como sua capacidade de controle de Meloidogyne incognita nos genótipos de soja CD206 e CD215. Em ensaio in vitro, para avaliar a capacidade inibitória de eclosão de juvenis, depositou-se 500 ovos/placa quantificando o número de juvenis eclodidos após 15 dias de incubação com 1\%, 5\% e $10 \%$ do extrato aquoso de alecrim. O ensaio in vivo foi conduzido em casa de vegetação climatizada, usando-se as mesmas concentrações do extrato de alecrim, pulverizado semanalmente sobre as plantas

${ }^{1}$ Eng $^{\text {a }}$ Agra , Discente do Curso de Doutorado em Produção Vegetal, Universidade Federal do Paraná, UFPR, Curitiba, PR, Brasil. E-mail: mo_ang@hotmail.com

${ }^{2}$ Eng $^{\mathrm{a}}$ Agr ${ }^{\mathrm{a}}$, Prof ${ }^{\mathrm{a}}$ M.e, Universidade Tecnológica Federal do Paraná, UTFPR, Pato Branco, PR, Brasil. E-mail: thaisamioranza@ hotmail.com

${ }^{3}$ Eng $^{\text {os }}$ Agr $^{\text {os }}$ Profs. Drs., Universidade Estadual do Oeste do Paraná, UNIOESTE, Marechal Cândido Rondon, PR, Brasil. E-mail: jose.stangarlin@unioeste.br; ojkuhn@gmail.com

${ }^{4}$ Eng $^{\circ}$ Agr ${ }^{\circ}$, Discente do Curso de Doutorado em Produção Vegetal, UNIOESTE, Marechal Cândido Rondon, PR, Brasil. E-mail: andre battistus@hotmail.com

${ }^{5}$ Eng $^{\text {os }}$ Agros , Autônomos, Toledo, PR, Brasil. E-mail: ademar istchuk@hotmail.com; ffuchs84@hotmail.com

* Author for correspondence 
pelo período de 64 dias, iniciando no estádio fenológico V3. Três dias após a primeira pulverização inoculou-se 1800 ovos e 400 juvenis de segundo estágio (J2). O número de ovos e J2 no solo e raiz, o número de galhas e o fator de reprodução foram determinados. Os resultados indicaram que in vitro, o extrato de alecrim reduziu a eclosão de juvenis. Em soja, verificou-se redução de $46,5 \%$ no número de galhas, além da redução no número de ovos no solo e no fator de reprodução para a cultivar CD 206. Para CD 215 houve redução no número de ovos e no fator de reprodução. Assim, o extrato aquoso de alecrim apresenta potencial para manejo de $M$. incognita em soja.

Palavras-chave: Controle alternativo, indução de resistência, nematoide de galha, Rosmarinus officinalis

Brazil ranks second among soybean producers in the world, producing approximately 86 million tons. Paraná is the second highest soybean grain producer among Brazilian states, harvesting 14.7 million tons in 2013/2014 season (COMPANHIA NACIONAL DE ABASTECIMENTO, 2014).

Diseases are a significant threat to the yield of soybean crops, with the estimated damage caused by the root-knot nematode (Meloidogyne incognita) being approximately 2.6 million tons (WRATHER et al., 2010).

Resistant cultivars and chemicals are commonly used to manage plant diseases, but these practices are effective for a limited number of diseases (WRATHER; KOENNING, 2006). Nematodes are frequently managed with nematicide, but this approach is expensive and poses environmental risks, prompting the need for alternative methods that are efficient and eco-friendly (ADEGBITE; ADESIYAN, 2005).

The excessive use of synthetic pesticides is creating toxicological and environmental problems, highlighting the importance of using plant products as ecologic alternatives for crop protection (GURJAR et al., 2012).

According to Stangarlin et al. (2011), plants used for pest control have secondary compounds that can activate latent defense mechanisms, including local and systemic resistance, in treated plants, and they can also have antimicrobial activity against plant pathogens, both properties making these unique plants useful alternatives in controlling plant disease.
The difficulty of managing nematodes along with the goal of restricting the use of chemical pesticides makes plant extracts with nematicidal properties attractive alternatives to small farmers because of their practical, economic value and minimal environmental risk (GARDIANO, 2009).

The move to find ways to induce plant resistance to nematodes has been increasing over recent years (DIAS-ARIEIRA et al., 2013). Plant extracts can control pathogens by direct antimicrobial activity or by inducing resistance to pests. For example, Tagetes patula extracts have been shown to control Meloidogyne incognita in tomatoes (FRANZENER et al., 2007), and essential oil of Rosmarinus officinalis can inhibit Meloidogyne javanica in soybeans (MATTEI et al., 2013). Borges et al. (2013) found through in vitro trials that Azadirachta indica, Curcuma longa, and Crotalaria breviflora extracts are directly toxic to Meloidogyne incognita and Tubixaba tuxaua.

Rosemary extract (Rosmarinus officinalis) has antibacterial and antifungal properties, as well as antioxidant activity in its leaves and stems (GENENA et al., 2008). In addition, rosmarinic acid, present in rosemary, has nematicidal proprieties (WANG et al., 2012).

Thus, the aim of this study was to evaluate both in vitro hatching and the control of Meloidogyne incognita in two soybean cultivars using rosemary extract.

The rosemary extract was prepared by collecting rosemary plants on a farm between 10:00 AM and 12:00 PM during the spring season. Identification 
of the plants was made using a botanical description (LORENZI; MATOS, 2002). The extract was prepared by grinding $10 \mathrm{~g}$ of leaves in a blender for $1 \mathrm{~min}$ and mixing with $100 \mathrm{~mL}$ of distilled water. The solution was then vacuum filtered through qualitative filter paper (pore diameter $8 \mu \mathrm{m}$ ), resulting in a $10 \%$ extract that was diluted with distilled water as necessary to obtain the needed treatment concentrations $(0 \%, 1 \%, 5 \%$, and $10 \%)$.

Six milliliters of extract was placed in a 50 $\mathrm{mL}$ plastic container with $0.5 \mathrm{~mL}$ of a nematode suspension that contained an average of $500 \mathrm{M}$. incognita eggs per $\mathrm{mL}$. Containers were kept for 15 days in the dark at $26^{\circ} \mathrm{C}$. After this period, the number of second-stage juveniles (J2) hatched was evaluated using a stereo microscope and Peter's slide.

Analysis was performed with a completely randomized design, which had four treatments and five replicates, totaling 20 experimental plots. Each cultivar was analyzed separately. Data were analyzed by variance, and when significant, by regression analysis. SISVAR was used for statistical analysis (FERREIRA, 2011).

In vivo assay was performed under greenhouse conditions at the Unioeste Experimental Facility, Mal. Candido Rondon Campus, PR, using a completely randomized design, with four treatments and five repetitions. Two soybean cultivars were used, CD 206 and CD 215, and four concentrations of rosemary aqueous extract were applied $(0 \%, 1 \%$, $5 \%$, and $10 \%$ ). Single soybean plants were placed in individual 2-L plastic pots with a mix of soil, sand, and organic compost $(2: 2: 1, \mathrm{v} / \mathrm{v} / \mathrm{v})$ that was sterilized by autoclaving for $1 \mathrm{~h}$ at $120^{\circ} \mathrm{C}$ and $1 \mathrm{~atm}$.

Starting at V3 stage, the soybean plants were sprayed weekly with the same concentration of rosemary extract for 64 days. The aerial parts were sprayed until leaf wetting, but stopped before draining. Three days after the first treatment, the plants were inoculated with $1800 \mathrm{M}$. incognita eggs and $400 \mathrm{~J} 2$ per plant. The nematodes were obtained from tomato plants following Taylor and Sasser's (1993) methodology, and identified by the perineal area as described by Hartman and Sasser (1985).

At the end of the experiment, the number of eggs and $\mathrm{J} 2$ in roots and soil $\left(100 \mathrm{~cm}^{3}\right)$ were evaluated, (JENKINS, 1964) and the number of galls in the roots and the RF were calculated as defined by Oostenbrink (1966).

Results of the in vitro trial for hatching $M$. incognita eggs exposed to rosemary extract showed a straight-line downward adjustment with increasing concentrations in the regression test. The eggs treated with the $10 \%$ concentration had the lowest hatching average, with only $14.8 \%$ of $\mathrm{J} 2$ hatched, which was $33.8 \%$ lower than the treatment group that was not exposed to rosemary extract (Figure 1). In addition to inhibiting egg hatching, Müller et al. (2014) showed that rosemary extract also has a nematostatic effect, ceasing up to $97 \%$ of M. incognita movements, and inducing up to $83 \%$ of $\mathrm{J} 2$ deaths.

Ferreira et al. (2013) examined the potential of multiple plant extracts to control $M$. incognita juvenile hatching, including Tridax procumbens, Tagetes patula, Tithonia diversifolia, Sphagneticola trilobata, Unxia suffruticosa, and Zinnia peruviana, and found that a $10 \%$ concentration extract reduced egg hatching by $89.96 \%, 91.13 \%, 92.48 \%, 92.72 \%$, $93.2 \%$, and $97.48 \%$, respectively, compared to the eggs that were not exposed to the extract. In our study using rosemary, we observed an even greater reduction in the number of eggs hatched.

Moreira et al. (2009), evaluated the effect of different concentrations of Lippia sidoides essential oil on egg hatching and found that concentrations greater than $0.625 \mathrm{~mL} \cdot \mathrm{L}^{-1}$ reduced the hatching of M. incognita juveniles. 
Figure 1. Effect of different concentrations of rosemary aqueous extract on the hatching of $M$. incognita juveniles.

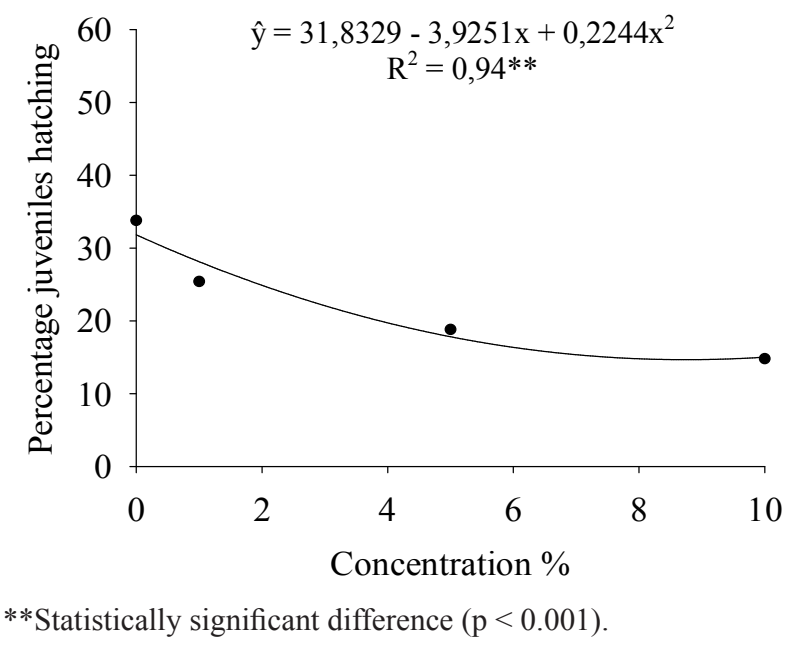

Ntalli et al. (2013) found that rosemary essential oil at $5.5 \mu \mathrm{g} \cdot \mathrm{mL}^{-1}$ and $500.0 \mu \mathrm{g} \cdot \mathrm{mL}^{-1}$ concentrations completely inhibited $M$. incognita juveniles from hatching. Rosemary essential oil consists mainly of monoterpenes (94.1\%), which is likely the active compound responsible for inhibiting juvenile hatching. There are higher concentrations of monoterpenes in essential oils than in aqueous extracts, due to the polarity of monoterpenes, some of their components do not dissolve in water, making them more effective in essential oils than aqueous extracts at reducing hatching.

After analyzing the chemical composition of essential oils from aerial parts of Pectis apodocephala and Pectis oligocephala, Albuquerque et al. (2007) confirmed that monoterpenes were the dominant component. Both essential oils resulted in a high death rate of $M$. incognita $\mathrm{J} 2$ after $72 \mathrm{~h}$ of contact, confirming their nematicidal activity.

Our in vivo results showed that rosemary extract reduced the number of galls, eggs, and J2 in 100 $\mathrm{cm}^{3}$ of soil, and the RF of the CD 206 cultivar.
Rosemary aqueous extract reduced galls in the CD 206 cultivar by $46.5 \%$ compared to water, resulting in 7.64 galls at $5.47 \%$ extract concentration (Figure 2A). In the CD 215 cultivar, there was a significant reduction in the variance analysis of the number of eggs, $\mathrm{J} 2$ in $100 \mathrm{~cm}^{3}$ of soil, and the RF.

According to Brand et al. (2010), a 3\% aqueous extract of dried rosemary leaves (in contrast to our study that evaluated fresh leaves), can induce phaseolin production in the hypocotyl of the beans. In addition, resistance-inducing agents in the extract stimulate phytoalexin production, which acts as a plant defense mechanism against pathogens. The reduction in the number of galls observed in $\mathrm{CD}$ 206 soybean plants in this trial can be explained by the systemic activation of defense mechanisms, because the extract was sprayed only on aerial parts and was not in direct contact with the root system. In pathosystem tomatoes exposed to $M$. incognita, Cetintas and Yarba (2010) observed a 50\% reduction in the number of galls after aerial application of rosemary leaf essential oil $\left(50 \mu \mathrm{L}^{-1}\right.$ and $150 \mu \mathrm{L}^{-1}$ concentrations) on the first day of inoculation. 
Figure 2. Effects of different concentrations of rosemary aqueous extract in the CD 206 soybean cultivar on the number of M. incognita galls (A), eggs in $100 \mathrm{~cm}^{3}$ of soil (B), J2 in $100 \mathrm{~cm}^{3}$ of soil (C), and RF (D).

A
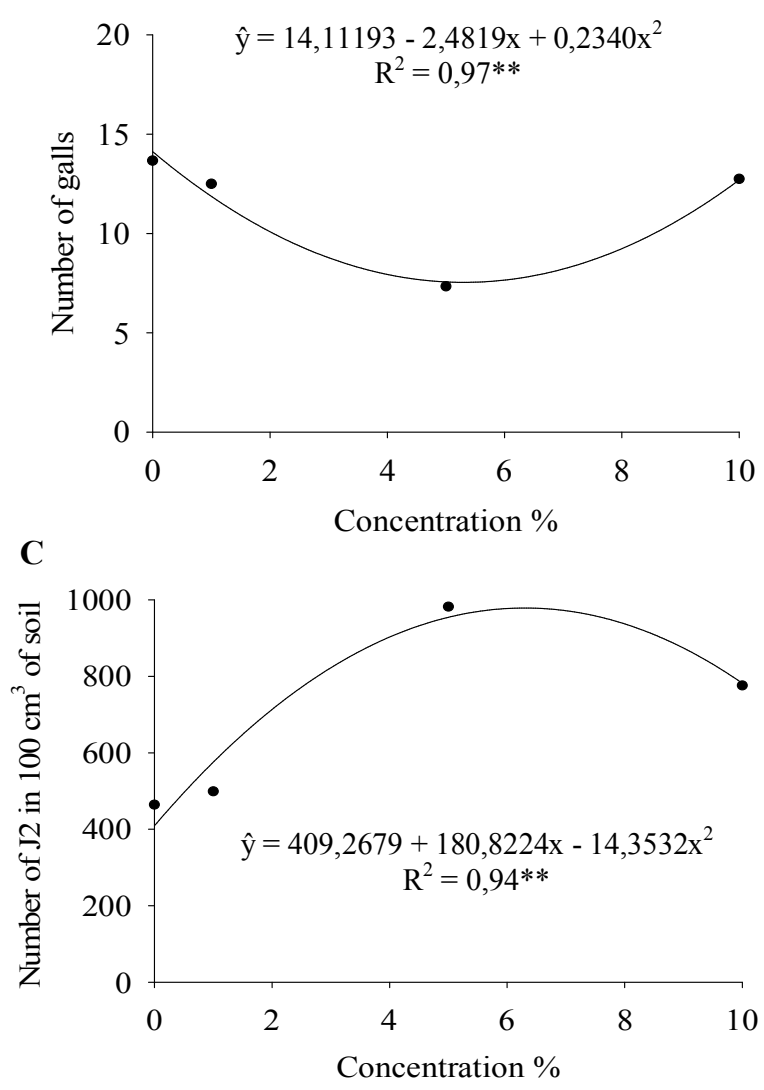

** Statistically significant difference $(\mathrm{p}<0.001)$.

Other pathosystems also show similar results; for example, Franzener et al. (2007) demonstrated that weekly applications of an aqueous extract made from the leaves and flowers of T. patula to tomatoes (soil and aerial parts) reduced the number of galls and the RF of M. incognita, suggesting that T. patula extract can activate systemic defense mechanisms in these plants.

We found that the highest concentration of rosemary extract $(10 \%)$ resulted in a greater number of galls, likely because of the metabolic stress induced by exposure to a high concentration of extract. Stangarlin and Kuhn (2009) found that tomato plants inoculated with Xanthomonas vesicatoria and treated with $10 \%$ rosemary extract produced fewer fruits because of the high metabolic

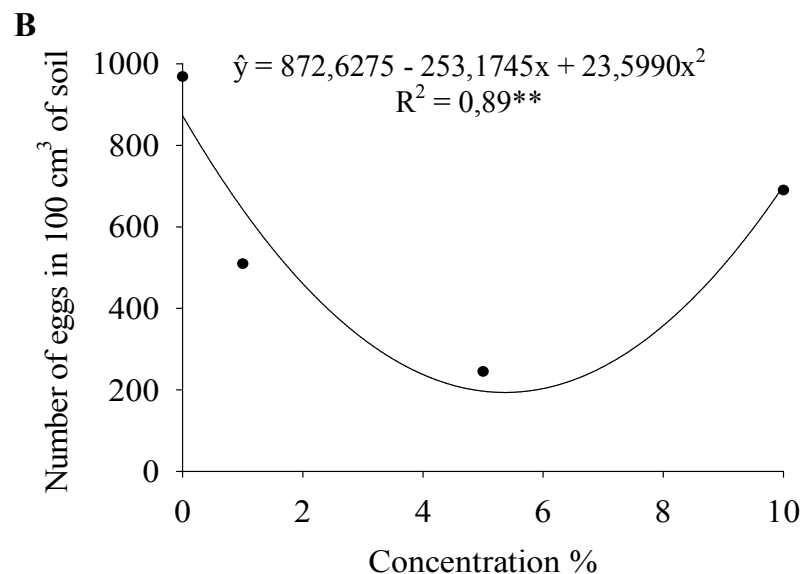

D

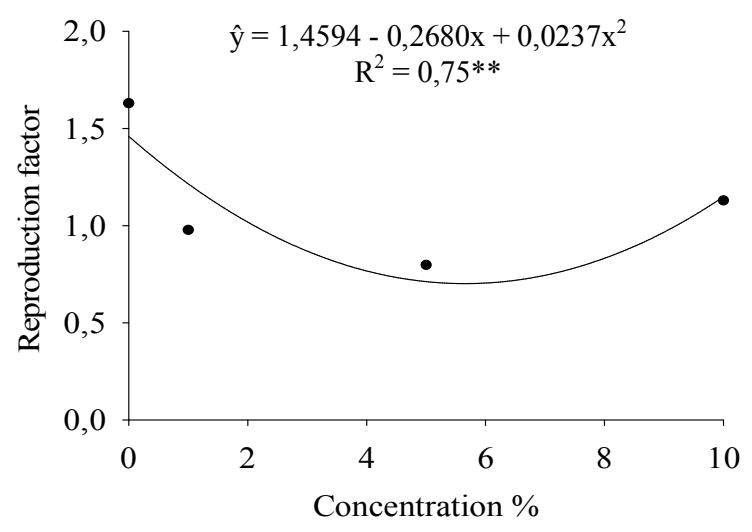

cost associated with the treatment. Furthermore, Mattei et al. (2013), after spraying CD 206 soybean plants with high concentrations ( $2 \%$ and $3 \%$ ) of rosemary essential oil, found that plants had reduced growth parameters, likely from phytotoxicity.

In both cultivars CD 206 and CD 215, the number of eggs in $100 \mathrm{~cm}^{3}$ of soil showed a quadratic relationship (Figures $2 \mathrm{~B}$ and $3 \mathrm{~A}$ ). For CD 206, as number of galls, the lowest number of eggs (193.62) was estimated at a rosemary extract concentration of $5.36 \%$. In CD 215, the lowest number of eggs (215.09) was found at a concentration of $6.63 \%$. The reduction in the number of galls at extract concentrations near $5 \%$ could be due to the systemic activation of resistance in the plant, which makes 
it more difficult for the $M$. incognita juveniles to penetrate the plant. The extract could also affect the development of females, resulting in a lower number of eggs in the soil (Figures $2 \mathrm{~B}$ and $3 \mathrm{~A}$ ). In contrast, the higher number of $\mathrm{J} 2$ in the soil (Figures $2 \mathrm{C}$ and $3 \mathrm{~B}$ ) could be a consequence of poor root penetration due to the activation of plant defense mechanisms, or changes in the rhizosphere caused by modifications in the quantity and/or composition of exudates released by plants treated with rosemary extract.
The RF values for CD 206 (Figure 2D) were less than 1 in extract concentrations of $1 \%$ and $5 \%$. The lowest number on this curve was 0.70 at a concentration of $5.65 \%$. Considering that the CD 206 cultivar is susceptible to M. incognita, these results support the hypothesis of induction of resistance in plants. A similar result was observed in CD 215 (Figure 3C) with RF values of less than 1 in plants treated with aerial application of rosemary extract, and the lowest number $(0.56)$ was noted at a concentration of $9.47 \%$.

Figure 3. Effects of different concentrations of rosemary aqueous extract in the CD 215 soybean cultivar on the number of M. incognita eggs in $100 \mathrm{~cm}^{3}$ of soil (A), J2 in $100 \mathrm{~cm}^{3}$ of soil (B), and RF (C).

A

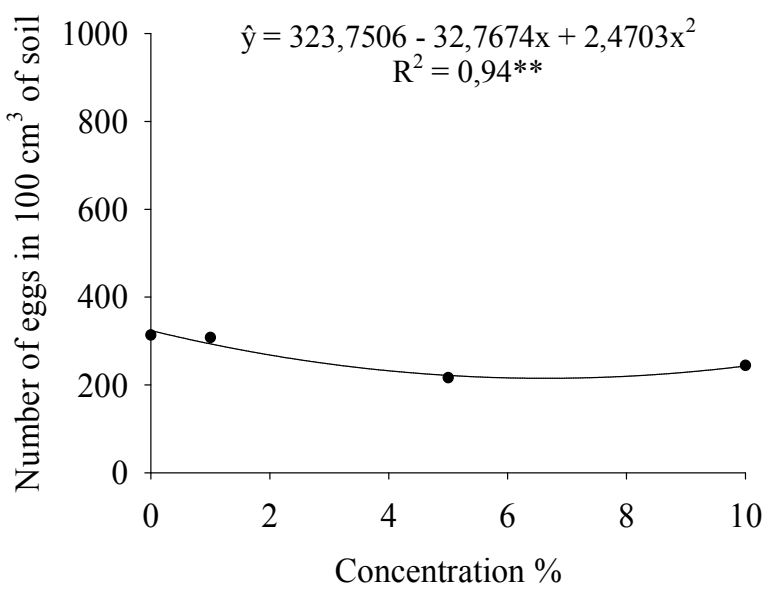

B

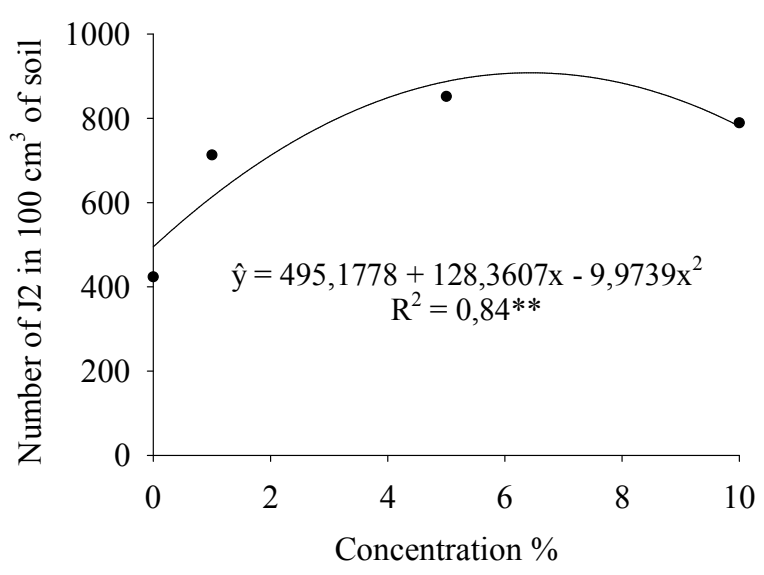

C

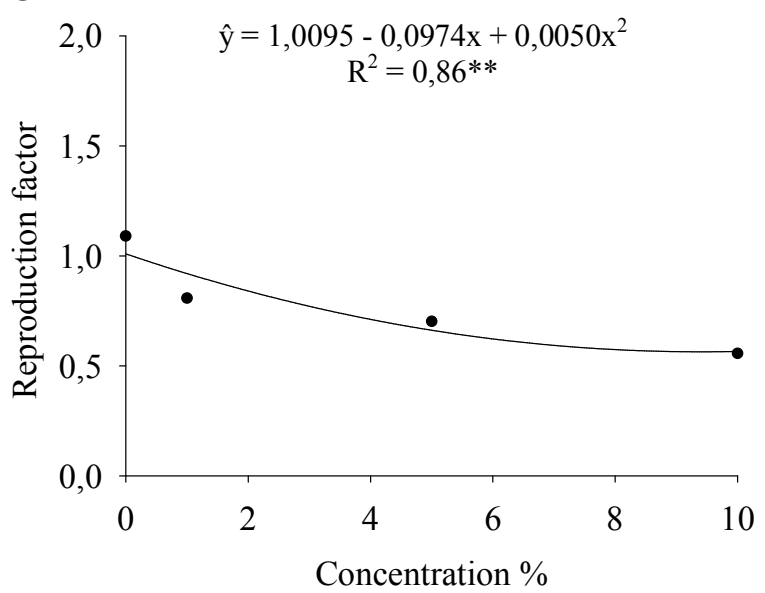

**Statistically significant difference $(\mathrm{p}>0.001)$. 
Lopes et al. (2005) suggest that the application of plant extracts can induce systemic nematicidal action by releasing toxic substances in the roots. Furthermore, plants treated with extracts could also release chemicals that affect the penetration and feeding of nematodes, impairing their development (galls) and reproduction (ALBUQUERQUE et al., 2010). This induced resistance may be responsible for the impaired release of the chemical stimulus necessary for the juvenile hatching and chemotaxis in the root of treated plants. These are areas for future trials to explore.

Azadirachta indica extract may also reduce the RF of $M$. incognita in tomatoes (0.46), compared to the control treatment (1.43) in an assay by Hadian et al. (2011). Essential oil of Cymbopogon citratus and Lavandula angustifolia, when sprayed on the aerial parts of rice, also showed potential to reduce the RF of Meloidogyne graminicola (STEFFEN et al., 2008).

Based on our results, we concluded that the aqueous extract of $R$. officinalis has the potential to control M. incognita nematodes in CD 206 and CD 215 soybean cultivars by a dose-dependent reduction in the number of $\mathrm{J} 2$ hatching, the number of galls, and the RF.

The authors thank Fundação Araucária de Apoio ao Desenvolvimento Científico e Tecnológico do Paraná which is affiliated with the Secretaria de Estado da Ciência, Tecnologia e Ensino Superior SETI, and we are also grateful to CAPES/PNPD and CNPq for financial support and for the Productivity Research Grant of JRS.

\section{References}

ADEGBITE, A. A.; ADESIYAN, S. O. Root extracts of plants to control Root-Knot Nematode on edible soybean. World Journal of Agricultural Sciences, New York, v. 1, n. 1, p. 18-21, 2005.

ALBUQUERQUE, E. V. S.; CARNEIRO, R. M. D. G.; COSTA, P. M.; GOMES, A. C. M. M.; SANTOS, M.; PEREIRA, A. A.; NICOLE, M.; FERNANDEZ,
D.; GROSSI-DE-AS, M. F. Resistance to Meloidogyne incognita expresses a hypersensitive-like response in Coffea arabica. European Journal of Plant Pathology, Wageningen, v. 128, n. 3, p. 365-373, 2010.

ALBUQUeRQUE, M. R. J. R.; COSTA, S. M. O.; BANDEIRA, P. N.; SANTIAGO, G. M. P.; ANDRADENETO, M.; SILVEIRA, E. R.; PESSOA, O. D. J. Nematicidal and larvicidal activities of the essential oils from aerial parts of Pectis oligocephala and Pectis apodocephala Baker. Anais da Academia Brasileira de Ciências, Rio de Janeiro, v. 79, n. 2, p. 209-213, 2007.

BORGES, F. G.; KUHN, O. J.; BATTISTUS, A. G.; ESTEVEZ, R. L.; COLTRO, S. Toxidade de tratamentos alternativos e químicos in vitro sobre Tubixaba tuxaua e Meloidogyne incognita. Scientia Agraria Paranaensis, Marechal Cândido Rondon, v. 12, p. 440-449, 2013. Suplemento.

BRAND, S. C.; BLUME, E.; MUNIZ, M. F. B.; MILANESI, P. M.; SCHEREN, M. B.; ANTONELLO, L. M. Extratos de alho e alecrim na indução de faseolina em feijoeiro e fungitoxicidade sobre Colletotrichum lindemuthianum. Ciência Rural, Santa Maria, v. 40, n. 9, p. 1881-1887, 2010.

CETINTAS, R.; YARBA, M. M. Nematicidal effects of five plant essential oils on the southern root-knot nematode, Meloidogyne incognita Race 2. Journal of Animal and Veterinary Advances, Islamabad, v. 9, n. 2, p. 222-225, 2010.

COMPANHIA NACIONAL DE ABASTECIMENTO - CONAB. Acompanhamento da safra brasileira de grãos. v. 1 - Safra 2013/14, n. 12 - Décimo Segundo Levantamento. Brasília: CONAB. 2014. 151 p.

DIAS-ARIEIRA, C. R.; SANTANA-GOMES, S. M.; PUERARI, H. H.; FONTANA, L. F.; RIBEIRO, L. M.; MATTEI, D. Induced resistance in the nematodes control. African Journal of Agriculture Research, Lagos, v. 8, n. 20, p. 2312-2318, 2013.

FERREIRA, D. F. Sisvar: a computer statistical analysis system. Ciência e Agrotecnologia: Lavras, v. 35, n. 6, p. 1039-1042, 2011.

FERREIRA, I. C. M.; SILVA, G. S.; NASCIMENTO, F. S. Efeito de extratos aquosos de espécies de Asteraceae sobre Meloidogyne incognita. Summa Phytopathologica, Botucatu, v. 39, n. 1, p. 40-44, 2013.

FRANZENER, G.; FRANZENER, A. S. M.; STANGARLIN, J. R.; FURLANETTO, C.; SCHWANESTRADA, K. R. F. Proteção de tomateiro a Meloidogyne incognita pelo extrato de Tagetes patula. Nematologia Brasileira, Campos dos Goytacazes, v. 31, n. 1, p. 27-36, 2007. 
GARDIANO, C. G. A atividade nematicida de extrato aquoso e tinturas vegetais sobre Meloidogyne javanica (Treub 1885) Chitwood, 1949. Semina: Ciências Agrárias, Londrina, v. 30, n. 3, p. 551-556, 2009.

GENENA, A. K.; HENSE, H.; SMÂNIA, A.; SOUZA, S. M. Rosemary (Rosmarinus officinalis) - a study of the composition, antioxidant and antimicrobial activities of extracts obtained with supercritical carbon. Food Science and Technology, Campinas, v. 28, n. 2, p. 463-469, 2008.

GURJAR, M. S.; ALI, S.; AKHTAR, M.; SINGH, K. S. Efficacy of plant extracts in plant disease management. Agricultural Sciences, Milão, v. 3, n. 3, p. 425-433, 2012.

HADIAN, S.; RAHNAMA, K.; JAMALI, S.; ESKANDARI, A. Comparing Neem extract with chemical control on Fusarium oxysporum and Meloidogyne incognita complex of tomato. Advances in Environmental Biology, Amman, v. 5, n. 8, p. 2052-2057, 2011.

HARTMAN, K. M.; SASSER, J. N. Identification of Meloidogyne species on the basis of differential host test and perineal pattern morphology. In: CARTER, C. C.; SASSER, J. N. An advanced treatise on meloidogyne: methodology. Raleigh: North Carolina State University Graphics, v. 2, p. 69-77, 1985.

JENKINS, W. R. A rapid centrifugal-flotation technique for separating nematodes from soil. Plant Disease Reporter, New Brunswick, v. 48, n. 9, p. 692, 1964.

LOPES, E. A.; FERRAZ, S.; FREITAS, L. G.; FERREIRA, P. A.; AMORA, D. X. Efeitos dos extratos aquosos de mucuna preta e manjericão sobre Meloidogyne incognita e Meloidogyne javanica. Nematologia Brasileira, Campos dos Goytacazes, v. 29, n. 1, p. 67-74, 2005.

LORENZI, H. E.; MATOS, F. J. de A. Plantas medicinais no Brasil: nativas e exóticas. Nova Odessa: Instituto Plantarum, 2002. $512 \mathrm{p}$.

MATTEI, D.; DIAS-ARIEIRA, C. R.; PUERARI, H. H.; DADAZIO, T. S.; ROLDI, M.; SILVA, T. R. B. Evaluation of Rosmarinus officinalis essential oil in inducing resistance to Meloidogyne javanica and Pratylenchus brachyurus in soybean. Food, Agriculture \& Environment, Helsinki, v. 11, n. 3, p. 1171-1175, 2013.

MOREIRA, F. J. C.; SANTOS, C. D. G.; INNECCO, R. Eclosão e mortalidade de juvenis J2 de Meloidogyne incognita raça 2 em óleos essenciais. Revista Ciência Agronômica, Fortaleza, v. 40, n. 3, p. 441-448, 2009.

MÜLLER, M. A.; MIORANZA, T. M.; FUCHS, F.; BATTISTUS, A. G.; STANGARLIN, J. R.; KUHN, O. J. Mortalidade e motilidade de Meloidogyne incognita em extrato aquoso de alecrim. Scientia Agraria Paranaensis, Marechal Cândido Rondon, v. 13, p. 343-346, 2014. Suplemento.

NTALLI, N. G.; NASIOU, E.; MENKISSOGLUSPIROUDI, U. Evaluation of essential oils from rosemary, orange, lavandula and false yellowhead on hatching and motility of root-knot nematode. Journal of Agricultural Science and Technology, Tehran, v. 3, n. 8, p. 603-616, 2013.

OOSTENBRINK, M. Major characteristics of the relation between nematodes and plants. Wageningen: $\mathrm{H}$. Veenman \& Zonen. 1966. 48 p.

STANGARLIN, J. R.; KUHN, O. J. Evidência de custo adaptativo da resistência induzida por ASM e extratos de plantas medicinais em tomateiro fertirrigado. Summa Phytopathologica, Botucatu, v. 35, p. 1-3, 2009. Suplemento.

STANGARLIN, J. R.; KUHN, O. J.; ASSI, L.; SCHWAN-ESTRADA, K. R. F. Control of plant diseases using extracts from medicinal plants and fungi. Science Against Microbial Pathogens: Communicating Current Research And Technological Advances, Badajoz, v. 2, n. 3, p. 1033-1042, 2011.

STEFFEN, R.B.;ANTONIOLLI,Z.I.; BOSENBECKER, V. K.; STEFFEN, G. P. K.; LUPATINI, M.; CAMPOS, A. D.; GOMES, C. B. Avaliação de óleos essenciais de plantas medicinais no controle de Meloidogyne graminicola em arroz irrigado. Nematologia Brasileira, Campos dos Goytacazes, v. 32, n. 2, p. 126-134, 2008.

TAYLOR, A. L.; SASSER, J. N. Biology, indentification and control of root-knot nematodes (Meloidogyne spp.). Raleigh: North Carolina States University, 1993. 111 p.

WANG, J.; PAN, X.; HAN, Y.; GUO, D.; GUO, Q.; LI, R. Rosmarinic acid from eelgrass shows nematicidal and antibacterial activities against pine wood nematode and its carrying bacteria. Marine Drugs, Basel, v. 10, n. 2, p. 2729-2740, 2012.

WRATHER, A.; SHANNON, G.; BALARDIN, R.; CARREGAL, L.; ESCOBAR, R.; GUPTA, G. K.; MA, Z.; MOREL, W.; PLOPER, D.; TENUTA, A. Effect of diseases on soybean yield in the top eight producing countries in 2006. Saint Paul: Plant Health Progress, 2010. Available at: <http://www.plantmanagementnetwork. org/pub/php/research/2010/loss/>. Accessed at: 10 jun. 2014.

WRATHER, J. A.; KOENNING, S. Estimates of disease effects on soybean yields in the United States 2003 to 2005. Journal of Nematology, Miami, v. 38, n. 1, p. 173180, 2006. 